\title{
New-generation taxoid SB-T-1214 inhibits stem cell-related gene expression in 3D cancer spheroids induced by purified colon tumor-initiating cells
}

Galina I Botchkina*1, Edison S Zuniga², Manisha Das², Yuan Wang1, Haichao Wang³, Shu Zhu³, Anne G Savitt4, Rebecca A Rowehl'4, Yan Leyfman², Jingfang Ju' ${ }^{1}$, Kenneth Shroyer ${ }^{1}$ and Iwao Ojima ${ }^{2}$

\begin{abstract}
Background: Growing evidence suggests that the majority of tumors are organized hierarchically, comprising a population of tumor-initiating, or cancer stem cells (CSCs) responsible for tumor development, maintenance and resistance to drugs. Previously we have shown that the CD133high/CD44high fraction of colon cancer cells is different from their bulk counterparts at the functional, morphological and genomic levels. In contrast to the majority of colon cancer cells expressing moderate levels of CD133, CD44 and CD166, cells with a high combined expression of CD133 and CD44 possessed several characteristic stem cell features, including profound self-renewal capacity in vivo and in vitro, and the ability to give rise to different cell phenotypes. The present study was undertaken for two aims: a) to determine stem cell-related genomic characteristics of floating 3D multicellular spheroids induced by CD133high/ CD44high colon cancer cells; and b) to evaluate CSC-specific alterations induced by new-generation taxoid SB-T-1214.

Results: Selected CSC phenotype was isolated from three independent invasive colon cancer cell lines, HCT116, HT29 and DLD-1. A stem cell-specific PCR array assay (SABiosciences) revealed that colonospheres induced by purified CD133high/CD44high expressing cells display profound up-regulation of stem cell-related genes in comparison with their bulk counterparts. The FACS analysis has shown that the 3D colonospheres contained some minority cell populations with high levels of expression of Oct4, Sox2, Nanog and c-Myc, which are essential for stem cell pluripotency and self-renewal. Single administration of the SB-T-1214 at concentration $100 \mathrm{nM}-1 \mu \mathrm{M}$ for $48 \mathrm{hr}$ not only induced growth inhibition and apoptotic cell death in these three types of colon cancer spheroids in 3D culture, but also mediated massive inhibition of the stem cell-related genes and significant down-regulation of the pluripotency gene expression. PCR array and FACS data were confirmed with western blotting. Importantly, viable cells that survived this treatment regimen were no longer able to induce secondary floating spheroids and exhibited significant morphological abnormalities.

Conclusions: We report here that a new-generation taxoid SB-T-1214 possesses significant activity against colon cancer spheroids induced by and enriched with drug resistant tumorigenic CD133high/CD44high cells and efficiently inhibited expression of the majority of stem cell-related genes. Our data indicates that the previously observed longterm efficacy of SB-T-1214 against drug resistant colon tumors in vivo may be explained by the down-regulation of multiple stem cell-related genes in the tumorigenic cell population, in addition to its known efficacy as a mitotic poison against proliferating cancer cells.
\end{abstract}

* Correspondence: gbotchkina@notes.cc.sunysb.edu

1 Department of Pathology, SUNY Stony Brook, NY, USA

Full list of author information is available at the end of the article

\section{Background}

With a worldwide cumulative incidence rate of $9.4 \%$, colorectal cancer is the second leading cause of cancer deaths when both sexes are combined [1]. Currently, anti- 
cancer drug development has a significantly lower success rate compared to other diseases [2], and this ineffectiveness of standard anti-cancer drugs has been attributed to the existence of relatively rare, highly drug resistant, quiescent or slow proliferating tumor-driving cells - cancer stem cells (CSCs). After the successful isolation and characterization of CSCs from all major types of human liquid and solid tumors [reviewed in ref. [3]] it became evident that CSCs are exclusively endowed with tumor-initiating capacity in the majority, if not all, cancer types, and are responsible for tumor sustaining, recurrence, metastasis and resistance to treatment. CSCs give rise to a hierarchy of actively proliferating, but progressively differentiating, tumor cells (committed progenitors), which contribute to the cellular heterogeneity of human cancers. Many types of CSCs, including tumorinitiating cells in brain $[4,5]$, kidney [6], liver $[7,8]$, colon $[9,10]$ and pancreatic [11] carcinomas were isolated and enriched using the cell surface marker CD133, or prominin-1 [12] alone or in combination with some other markers. Another commonly used cell surface marker is CD44 [13-22]. This glycoprotein is involved in many cellcell interactions, stemness and tumor development, in part via $\beta$-catenin and Wnt signaling activation of the CD44 gene transcription $[23,24]$. It was demonstrated earlier that the full range of CD44 alternatively spliced variants is widely expressed in normal and tumor colonic cells located in the crypt base [25], known as a colonic stem cell niche. Numerous studies have demonstrated that both $\mathrm{CD} 133^{+}$and $\mathrm{CD} 44^{+}$cells are highly tolerant to anti-cancer therapies [21,26-33], and moreover, the number of CSCs can be significantly increased after treatment [28,34-38]. The ratio of $\mathrm{CD} 133^{+}$cells correlates with tumor aggressiveness, histologic grade and clinical outcome [5,39-42]. Similar data were reported for CD44positive cells [21].

Since CSCs are naturally resistant to chemotherapy due to multiple mechanisms, including their relative quiescence, profound capacity for DNA repair, activation of the ATP-binding cassette $(\mathrm{ABC})$ transporters that efflux many standard anticancer agents, resistance to apoptosis and others [43-45], it is conceivable that effective anticancer drugs must be specifically targeted toward CSCs, not only to bulk tumor cells. Colon cancer is inherently drug-resistant due to multiple mechanisms that are still poorly characterized, so both the stem cells and the variably differentiated cells that comprise the proliferative pool of the colorectal carcinoma can potentially contribute to chemotherapy tolerance. The CSCs are biologically distinct from differentiated normal and cancerous cells; therefore, the search for therapies that are specific for CSCs should be focused on differences in gene expression patterns between these cell types. Previously we have shown that several new-generation taxoids, which were developed as an attempt to improve widely used taxanebased anticancer agents [46], exhibited cytotoxicity 2-3 orders of magnitude higher than commonly used paclitaxel and docetaxel against drug resistant breast cancer cells overexpressing the Pgp efflux pump [47,48]. One of these taxoids, SB-T-1214, also exhibited high efficiency against colon cancer in vivo, inducing complete regression of drug-resistant colon tumor xenografts in all surviving mice with tumor growth delay up to 201 days [49]. Such promising antitumor activity of SB-T-1214 led us to suggest that this compound can specifically target tumorspecific CSCs by inhibiting some stemness-related signaling pathways and/or promoting their differentiation. Since CSC-enriched $\mathrm{CD} 133^{+}$and $\mathrm{CD} 44^{+}$cell populations are more resistant to conventional therapies than other more differentiated cells [21,26-33], it was important to test cytotoxic effects of SB-1214 against these cell phenotypes. Since CSCs represent a dynamic population with dual potential, self-renewal versus generation of the committed progenitors, which eventually will differentiate into all mature cell phenotypes, the isolated CSCs was cultured, tested and treated under conditions designed to retain their "stemness" and preclude differentiation to the bulk tumor cells. Recent discovery of the possibility to reprogram adult differentiated epithelial cells into induced pluripotent stem cells by introduction of several essential transcription factors (Oct4, Sox2, c-Myc and Klf4) that determine cell stemness/differentiation state and regulate stem cell self-renewal [50,51], makes these genes an important target for anticancer drug development. The present study was thus undertaken for two aims: a) to determine the stem cell-related genomic differences between CSC-enriched floating colonospheres grown from CD133 high/CD44 $4^{\text {high }}$ cells in comparison to their bulk counterparts using three independent colon cancer cell lines; and b) to evaluate CSC-specific alterations induced by new-generation taxoid SBT-1214.

\section{Results}

A new-generation taxoid SB-T-1214 was evaluated for its efficacy against several drug-resistant human tumor xenografts, including colon tumors (Pgp+ DLD-1) in severe combined immune deficient (SCID) mice in our previous study [49]. The drug was administered intravenously in three doses 3 times using a 3-day regimen (q3d $\times 3$, on day 5,8 , and 11 ), starting from day 5 after DLD- 1 subcutaneous tumor implantation (results are summarized in Table 1). As anticipated, paclitaxel was ineffective against this highly drug-resistant $(\mathrm{Pgp}+)$ tumor at its optimal dose $(60 \mathrm{mg} / \mathrm{kg}$ total dose). In contrast, SB-T1214 has shown profound antitumor activity. The best result was obtained at $60 \mathrm{mg} / \mathrm{kg}$ total dose, $20 \mathrm{mg} / \mathrm{kg} \times 3$, wherein complete regression of the DLD-1 tumor was achieved in five of five mice (tumor growth delay was 
Table 1: Antitumor effect of SBT-1214 delivered i.v. to SCID mice bearing PgP+ DLD-1 human colon tumor xenografts.

\begin{tabular}{|c|c|c|c|c|c|c|c|c|}
\hline Treatment $^{\mathrm{a}}$ & Sche-dule & $\begin{array}{l}\text { Total Dose } \\
\text { (mg/kg) }\end{array}$ & $\begin{array}{l}\text { Dose/inj } \\
\text { (mg/kg) }\end{array}$ & $\begin{array}{l}\text { Days to } \\
600 \mathrm{~mm}^{3}\end{array}$ & $\begin{array}{c}\text { Pvalue } \\
\text { (Control) }\end{array}$ & $\begin{array}{c}\text { Growth Delay } \\
\text { (days) }\end{array}$ & Toxicityc & $\begin{array}{l}\text { Cured Mice } \\
\text { per groupd }\end{array}$ \\
\hline Control & & 0 & 0 & 17 & --- & --- & 0 & $0 / 10$ \\
\hline Vehicle-tween & $q 3 d \times 3$ & 0 & 0 & 16 & .405 & -1 & 0 & $0 / 4$ \\
\hline Paclitaxel & $q 3 d \times 3$ & 60 & 20 & & $<.001$ & 8 & 0 & $0 / 5$ \\
\hline SB-1214 & $q 3 d \times 3$ & 30 & 10 & 54 & $<.001$ & 37 & 0 & $0 / 5$ \\
\hline SB-1214 & $q 3 d \times 3$ & 60 & 20 & $>201$ & $<.001$ & $>150$ & 0 & $5 / 5$ \\
\hline SB-1214 & $q 3 d \times 3$ & 120 & 40 & $>201$ & .001 & $>150$ & 2 & $3 / 5$ \\
\hline
\end{tabular}

aTreatment given IV to SCID mice on day 5 after DLD-1 human colon tumor implant, and continued as noted; all drugs formulated in Tween/EtOH bBased on comparison of each group vs. control using the Cox-Mantel Test cNumber of animals who either died or lost greater than $20 \%$ body weight dSCID mice with no palpable tumor at end of experiment day 167.

$>201$ days). Systemic toxicity profile has shown that there was only a $3-5 \%$ weight loss during the period of day 15 to day 20 , and the drug was well tolerated by animals. Histopathological analysis of the hematoxylin and eosin stained tissue sections of the tumor xenografts recovered from the control (vehicle treated) mice revealed a large tumor areas with densely packed tumor cells (Figure 1A), which uniformly expressed membrane-bounded immunoreactivity for human epithelial cell adhesion molecule, $h$ EpCAM (Figure 1B; $h$ EpCAM-FITC; Biosource, CA, USA). Several small clusters of cells with high levels of CD133 expression were found predominantly within the outer areas of the tumors corresponding to the tumor invasive front (Figure 1C), and scattered CD133+ cells were detected across the entire tumor areas. Flow cytometry analysis of the dissociated and immunomagnetically sorted (MACS- $h$ EpCAM) mice tumor xenografts confirmed the presence of a minor population (about 4\%) of human cancer cells with high combined expression of the CD133 and CD44 (Figure 1D). After three consequent treatments with the SB-T-1214, we observed a complete reduction in tumor volume (Figure 1E). Residual tissues showed multiple inflammatory infiltrates and fibrosis (not shown), and they were negative for human EpCAM (F) and CD133 (G). Since SB-T-1214-treated mice did not show any presence of human cells, FACS analysis of the mice tissues was not performed.

\section{Isolation, purification and propagation of colon CSC phenotype}

To study the effects of SB-T-1214 specifically targeted to colon CSCs, we have selected three independent colon cancer cell lines, including DLD-1, which was used in our previous in vivo studies of the antitumor activity of SB-T1214, and two other highly invasive colon cancer cell lines, HCT116 and HT29. We have found that the vast majority (bulk) of all types of cells grown at standard adherent conditions expressed moderate levels of CD133 and CD44 (Figure 2; A-C). However, all three cell lines possessed minority cell populations with highest expression of CD133, which coincided with high expression of CD44 (CD133high/CD44high; red squares on A-C). Previously, we have characterized this phenotypic subpopulation in colon and prostate cancers by functional and genome-wide analysis, and demonstrated that these cells have profound self-renewing capacity in vivo and in vitro,

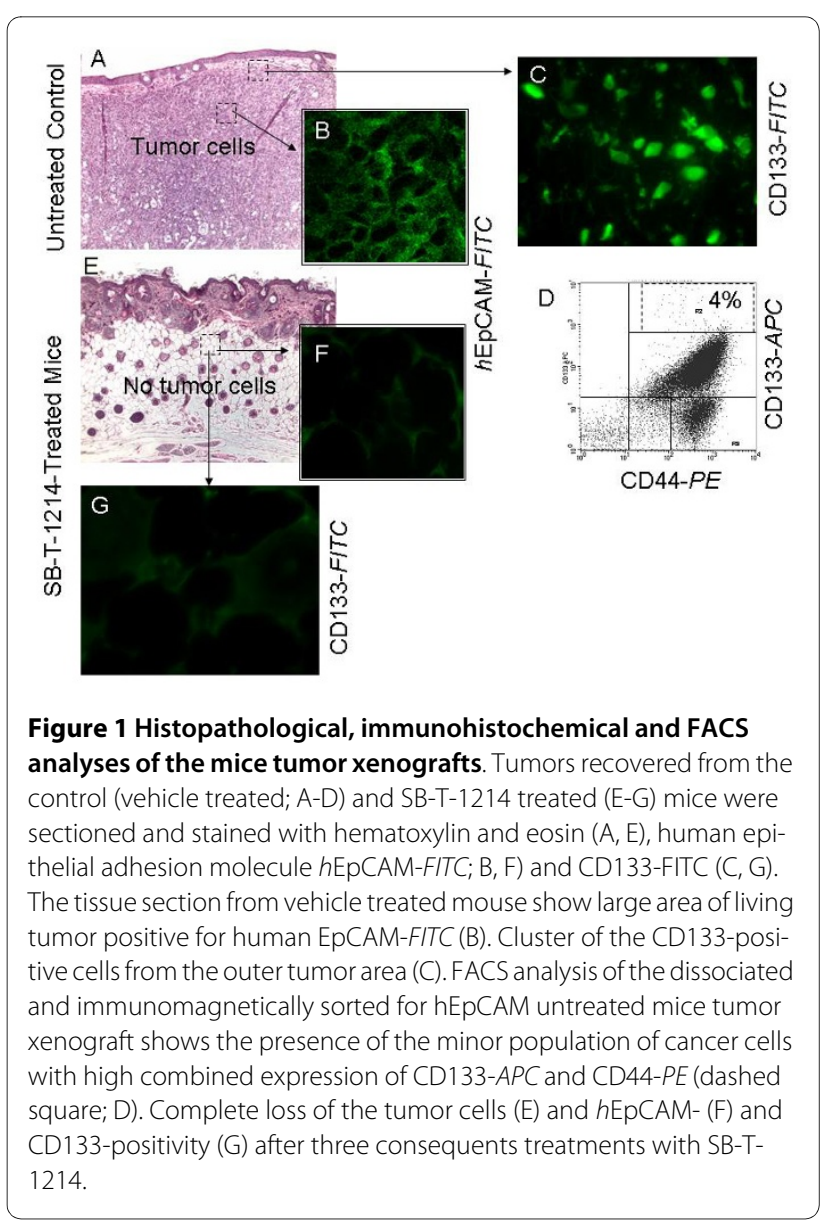


and 3D spheroids induced by this cell phenotype possessed stem-like features in contrast to their bulk counterparts $[19,20]$. Even without additional purification, the acutely isolated CD133high/CD44high cells derived from all three colon cancer cell lines possessed relatively high efficiency in forming dense floating multicellular spheroids in non-adherent cultures with serum-free medium (Figure 2; A-C), in contrast to their corresponding bulk counterparts, which produced a few loose flat colonies (not shown). The HCT116 spheroids revealed higher efficiency (one of 66 isolated cells induced dense 3D spheres) compared to HT29 (one of 175 cells) and DLD-1 (one of 118 cells). Dissociated spheroid cells retained an original cell phenotype and expressed all the studied commonly used stem cell surface markers, including CD133, CD44, CD166, hEpCAM, CD49b, and CD117 (CD133high/ CD44high population is shown on Figure 2; D-F, dashed squares). Immunohistochemical analysis revealed a minority cell population expressing high levels of nuclear $\beta$-catenin (not shown). Induced multicellular spheroids

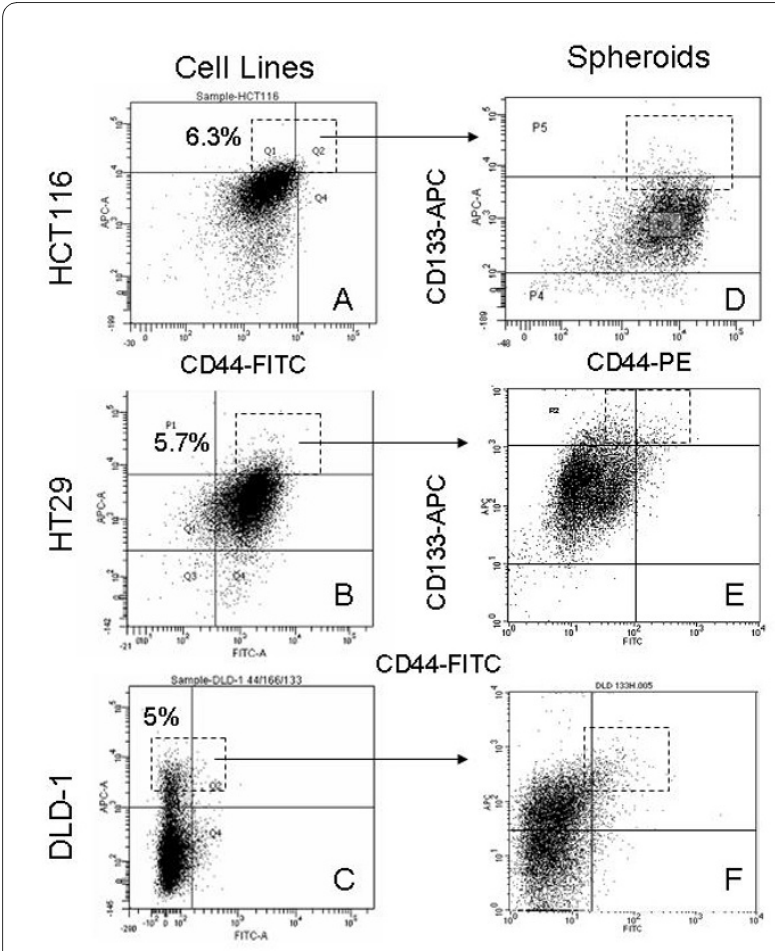

Figure 2 The CD133 high/CD44high phenotypic cell population has high sphere-forming capacity in the three independent colon cancer cell lines HCT116, HT29 and DLD-1. Cells grown at standard culture conditions possessed the minority phenotypic subpopulations with high combined levels of expression of CD133 and CD44 (left panel; outlined by dashed squares). The sphere-forming efficiency of these cells was 1 of 66 for HCT116 cell line, 1 of 175 for HT29, and 1 of 118 for DLD-1 cell line. In contrast, bulk cancer cells could induce only a few loose flat colonies under non-adherent culture conditions. Induced spheroids retained original cell phenotypes (right panel). were further tested for the expression of stem cell-related genes and CSC-related activity of SB-T-1214 in comparison to their bulk counterparts using PCR array assay (SABiosciences). However, these experiments required not only enriched CSCs, but also culture conditions which allow for retaining of the stem-like phenotype during drug treatment. Previously, we have found that additional purification of CD133 high/CD44high cell population by repeated sets of cell sorting followed by culturing at low cell density on type I collagen in serum-free stem cell medium led to significantly higher in vivo tumorigenic potential and sphere forming capacity of this cell phenotype $[19,20]$. In addition, the levels of expression of these markers and the ratios of CD133 high/CD44high cells in both mice tumor xenografts and colonospheres were also higher after transplantation of the purified cell populations. Our observations are in line with recent data showing that type I collagen indeed promotes the expression of a stem cell-like phenotype in human colorectal cancer and increases the expression of CD133 [52]. These approaches were used for growing 3D spheroids enriched with highly tumorigenic and clonogenic cells to be able to reveal genomic differences between these relatively rare cells in comparison to their much more numerous bulk counterparts. They were also used as target populations for studying CSC-specific drug effects.

\section{Cytotoxic effects of SB-T-1214 against CSC-enriched colon cancer cells}

The CSC-specific cytotoxic effects of SB-T-1214 were studied in two different settings which promote stemness phenotype: monolayer adherent to type I collagen cultures and three dimensional cultures of floating spheroids. In a first setting, the FACS sorted CD133high/ CD44high cells isolated from peritoneal fluid of metastatic colon cancer patients or from the established colon cancer cell lines were plated on the type I collagen-coated plates and cultured in the MSCB serum-free medium for 1-2 days before treatment. After 48 hours of incubation with the drug in concentration ranging from $100 \mathrm{nM}-1$ $\mu \mathrm{M}$, a majority $(89-96 \%)$ of all cell types underwent apoptosis [Figure 3; shown HCT116 cells (A-C); and peritoneal wash from metastatic colon cancer patient (D-F)]. Although about $4-11 \%$ of cells survived this treatment regimen, such cells displayed multiple abnormalities, including a greatly enlarged size (G-I, K), multiple nuclei (E, G-I), a significant increase in the number of long (J), and knobby (F, I) projections and severe vacuolization (K). Many cells displayed a clear sign of the mitotic catastrophe (G-I).

Next we have studied the SB-T-1214 cytotoxicity against colon cancer spheroids induced by CD133 high/ CD44high cells in 3D cultures. Administration of 0.1-1 $\mu \mathrm{M}$ SB-T-1214 for 48 hours induced a loss of integrity of the 


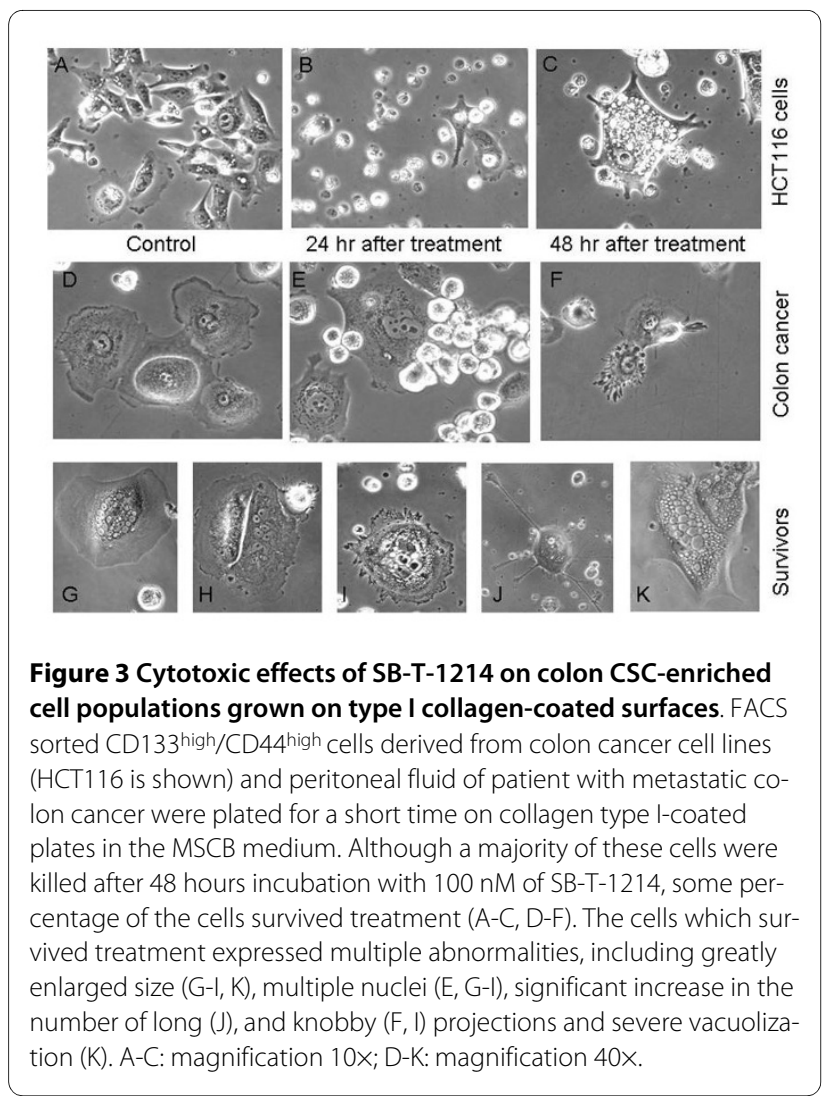

floating spheroids (Figure 4, A-C) and apoptosis in more than $90 \%$ of the sphere cells (D, E). The FITC-conjugated drug revealed efficient penetration into spheroids (C; 30 min exposure). Most importantly, viable cells which survived this treatment regimen significantly lost the ability to form secondary spheroids, which indicates that colon CSC population was critically affected (Figure 4, F). Thus, 1000 of untreated HCT116 primary spheroid cells induced $125 \pm 6$ secondary spheroids, HT29 - 75 \pm 7 , and DLD-1 gave rise to $93 \pm 6$ secondary spheroids, whereas the SB-T-1214-treated dissociated spheroid cells produced only $1.5 \pm 0.3,4 \pm 0.6$, and $3 \pm 0.4$ secondary spheroids, correspondently $(P<0.01)$. After placement on type I collagen surfaces, cells that survived drug treatment, displayed profound morphological abnormalities similar to those described above (Figure 3, G-K)

\section{Alterations in the stemness-related gene expression profile induced by SB-T-1214 \\ The CD133 high/CD44high cell populations derived from the three analyzed colon cancer cell lines were character- ized with the stem cell pathway-specific PCR Array assay (SABiosciences). Each array contains SYBR Green-based real-time PCR gene-specific assays for a set of 84 genes. Using filtering criteria of a 1.5 or greater fold-change in expression, we have analyzed differentially expressed genes in these three types of floating colonospheres com-}

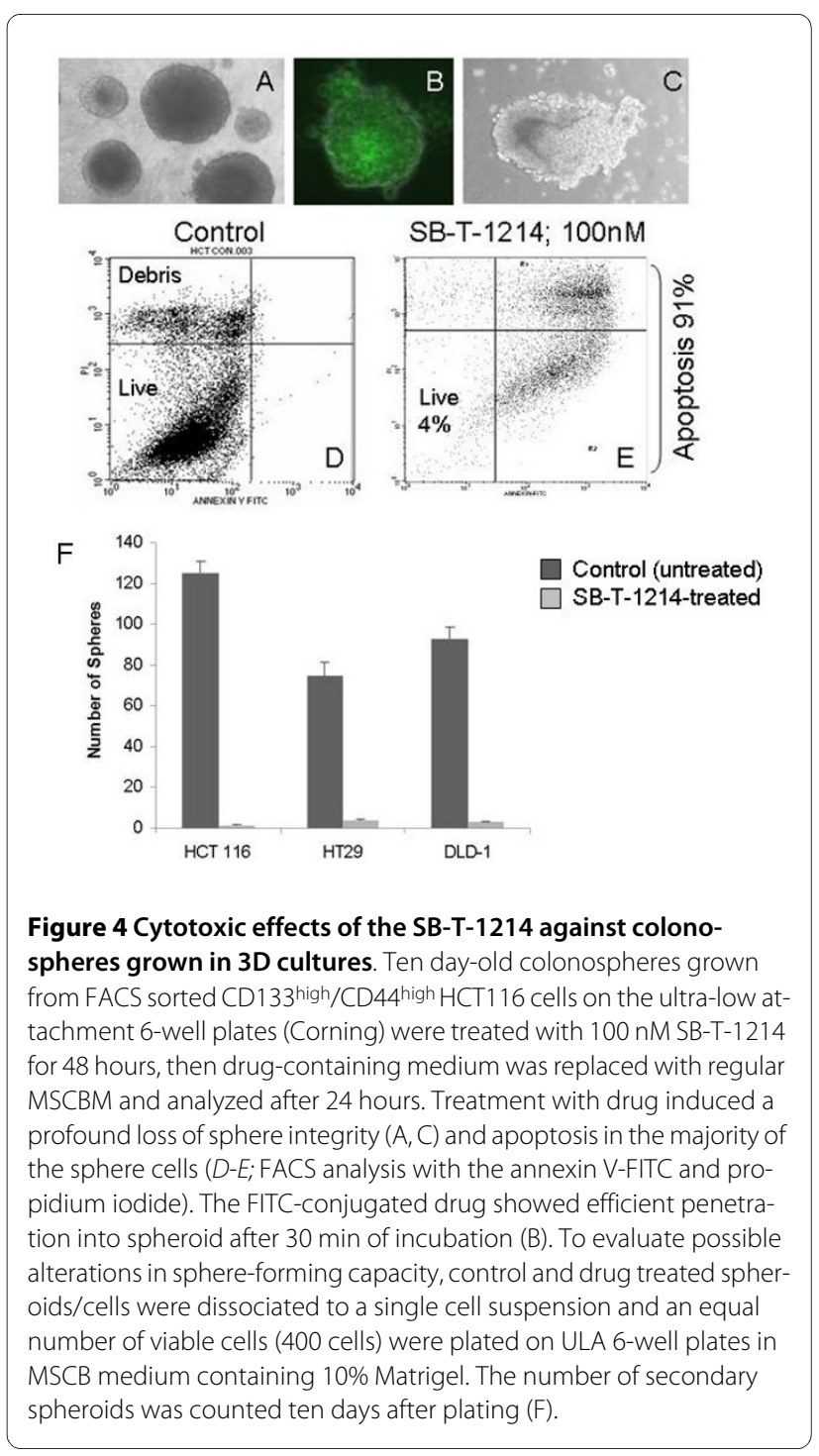

pared to their bulk differentiated adherent counterparts, as well as before and after treatment with SB-T-1214. The most profound differences were observed in HCT116 spheroids grown from CD133 high/CD44 high cells (Figure 5; left panel), which is in line with their higher sphere-forming and tumor-initiating capacities. About one-fourth of the analyzed stem cell-related genes, including Wnt and Notch pathway genes responsible for self-renew and cell cycle regulation, were commonly up-regulated in all types of spheroids, with significantly higher levels of expression in HCT116 ones. Thus, 6 of 6 analyzed genes responsible for stem cell self-renewal (SOX1, SOX2, MYST1, MYST2, NEUROG2 and HSPA9), and 3 of 5 genes regulating symmetrical/asymmetricasl cell division (NOTCH1, NOTCH2 and PARD6A) were significantly up-regulated in the HCT116 CD133/CD44-high colonospheres compared to their bulk counterparts. The most significantly up-regulated genes in HT29 spheroids 


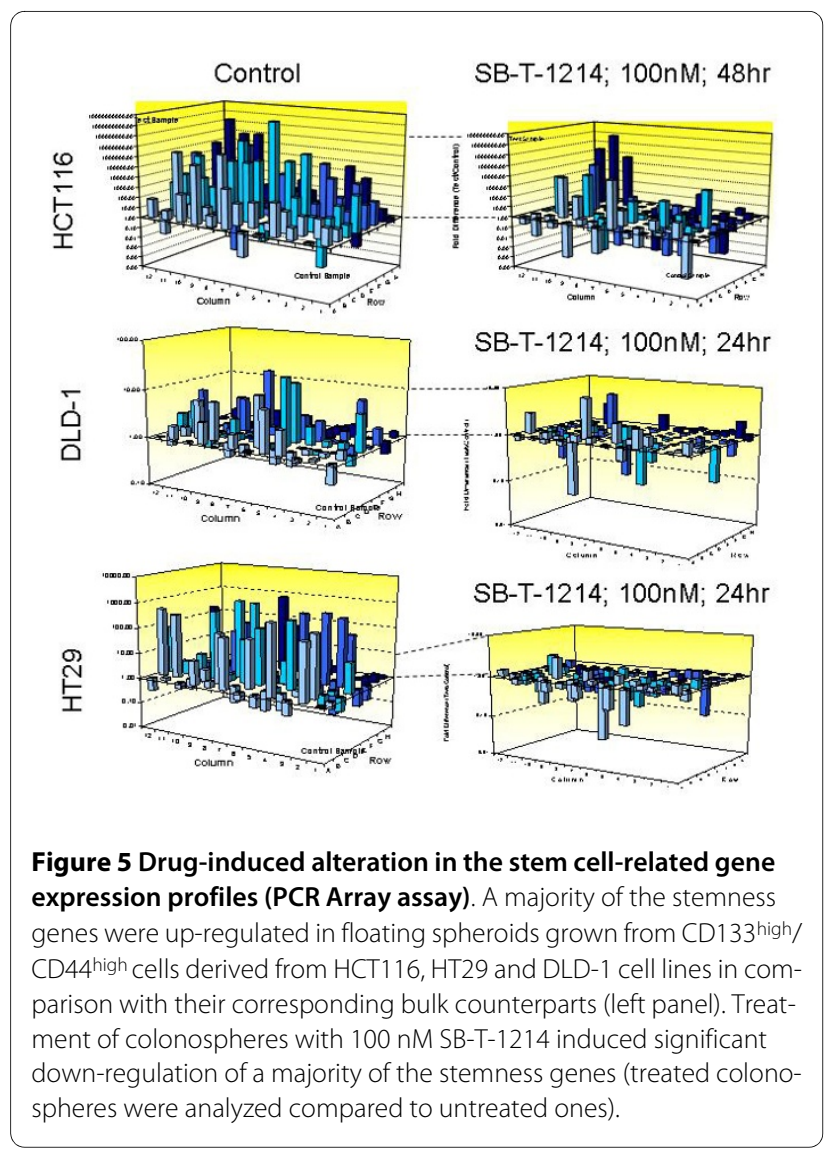

were $A C A N, A L P I, A P C, A S C L 2, C C N D 2$, CD3D, CD4, CD8A, CD8B, COL2A1, COL9A1, DHH, DLL3, DTX1 FGF1, GJA1, S1OOB, SOX2, T, TERT and WNT1; and in DLD-1 spheroids - ALDH1A1, ASCL2, CCND2, CD4, COL1A1, DLL1, DTX1, FGF1, GJA1, IGF1, JAG1, MME, NCAM1, and NOTCH1.

Importantly, relatively low concentrations of SB-T-1214 (100 nM-1 $\mu \mathrm{M}$ for 24 or $48 \mathrm{hr}$ ) induced dramatic downregulation of stemness in the majority of stem cell-related genes in all three types of colonospheres (Figure 5, right panel). The most significant drug-induced down-regulation of gene expression was detected: 1) in HCT116 colonospheres for SOX1, RPL13A, BMP3, NEUROG2, GJB1, GJA1, ASCL2, CTNNA1, GDF2, ALPI, S100B, CD8B1, ACTB, CCND1, FGF1, PARD6A, DVL1, GDF3, ISL1, CD3D, MME, FGFR1, RB1, BMP1, AIN1, ALDH1A1, CD8A, PPARD, FZD1, NUMB, ABCG2; 2) in HT29 colonospheres for ACAN, ALPI, BMP3, CD3D, CD4, CD8A, CD8B, CDH2, COL2A1, COL9A1, DHH, DLL1, DLL3, DTX1, FGF1, FGF3, FZD1, GDF2, IGF1, MME, MYOD, NCAM1, NEUROG2, S1OOB, SOX2, and $T E R T$; 3) in DLD-1 colonospheres for $C D 4, C D H 2$, COL1A1, DLL1, DTX1, IGF1, FGF3, FZD1, JAG1, KRT15, MSX1, NCAM1 and NOTCH1. Of note, many of these genes were related to the stem cells self-renewal, regulation of symmetric/asymmetric division and pluripotency.
We have found that the colonospheres induced by HCT116 cells with CD133 high/CD44 high phenotype contained minority cell populations with high levels of expression of several markers, which are essential for pluripotency and self-renewal of embryonic stem cells, including Oct4, Sox2, Nanog and c-Myc (Figure 6A). To analyze possible drug-induced alterations in the expression of these stem cell-specific transcription factors, which are low in abundance and present in a minority of colon cancer cell populations, we treated floating spheroids with $100 \mathrm{nM}$ of SB-T-1214 for 24 hours to induce such alterations, but avoid profound cell death. Importantly, both FACS and western blot analyses have shown that the expression of these key pluripotency markers was suppressed even after single treatment with relatively low drug concentration (Figure 6B; western blot analysis is shown). Off note, we have determined that GAPDH expression was stable in all cell phenotypes, in contrast to other housekeeping genes, which is in line with recent report [53].

\section{Discussion}

Increasing evidence indicates that effective anticancer drugs should target cancer-specific tumor-initiating cells, which are functionally and morphologically different from their bulk tumor counterparts. In our previous studies we found that in several analyzed clinically aggressive metastatic colon cancer specimens, as well as in the established colon cancer HCT116 cell line derived from a poorly-differentiated colonic adenocarcinoma, the majority of cells expressed low-to-moderated levels of CD133, CD44 and CD166 [20]. However, FACS analysis

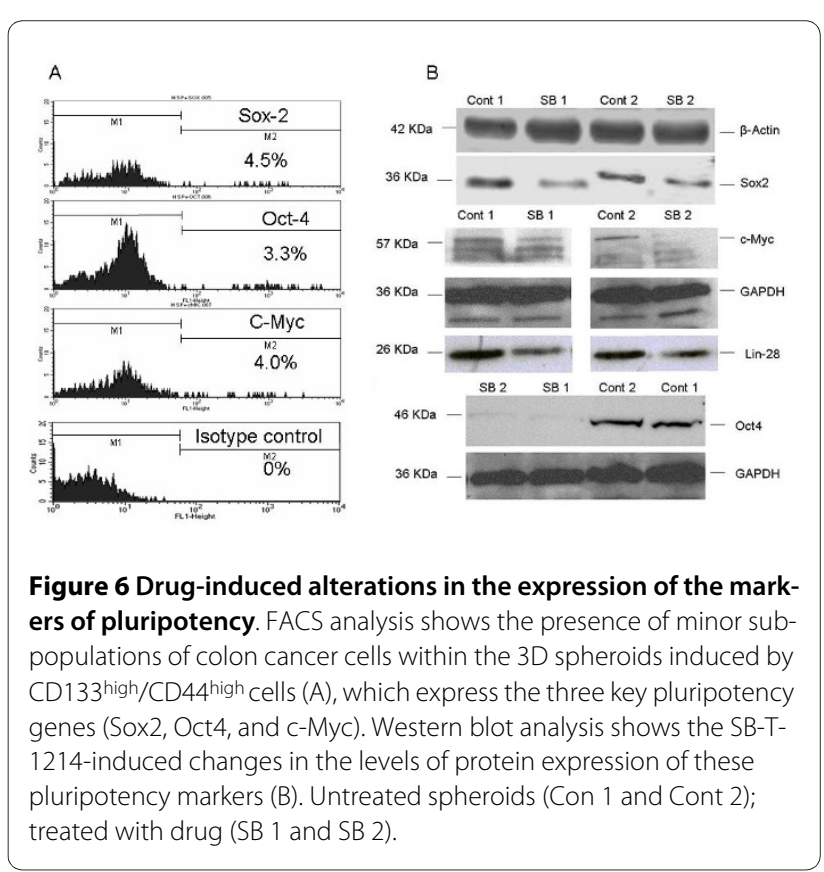


clearly showed the presence of the minority cell population with highest levels of combined expression of the CD133 and CD44. In contrast to the major bulk cell population, CD133high/CD44high phenotype possessed high tumorigenic and clonogenic capacities after serial transplantations of the low cell numbers, and was able to produce cells of all the original phenotypes, showing characteristic stem cell plasticity [54]. Original cell phenotypes were retained in both mice tumor xenografts and floating colonospheres induced by CD $133^{\text {high }} / \mathrm{CD} 44^{\text {high }}$ cells, suggesting that they represent the tumor-initiating, or colon CSCs in a HCT116 cell line. Moreover, both mice tumors and spheroids induced by highly purified CSCs contain higher ratios of cells with original transplanted phenotypes compared to original sources, which is in line with other studies [55]. Genome-wide gene expression analysis with the Affymetrix DNA microarray assay revealed that in a $\mathrm{CD} 133^{\text {high }} / \mathrm{CD} 44^{\text {high }}$ cell population, many genes related to drug resistance and stemness, including NOTCH, Shh, Wnt, Oct4, were significantly upregulated compared to their bulk counterparts [20]. In the present study we further characterized this colon CSC phenotype using pathway-specific gene expression profiling with PCR Array assay (SABiosciences) in the three independent colon cancer cell lines, HCT116, HT29 and DLD-1. We have found that CD133igh/ CD44high cell phenotype was present in all these cell lines, possessed relatively high sphere-forming capacity, and induced spheroids which expressed upregulated levels of the majority of stem cell-related genes compared to their differentiated counterparts. However, HCT116 cell populations revealed significantly higher expression of the stemness genes and higher sphere-forming potential compared to HT29 and DLD-1.

There is accumulating knowledge that tumor-initiating cells in metastatic colon cancer may not be demarcated solely by the expression of CD133 [18,56]. Although both CD44 and CD133 were reported as putative markers for many cancer-specific CSCs, including colorectal cancer (described in Introduction), it remains to be resolved whether they are of equal functional importance and what are their interrelationships. A recent study has demonstrated the unique role of CD133 in the normal and malignant colon, showing that $\mathrm{CD}_{133^{+}}$normal stem cells at the base of crypts in the adult intestine (a stem cell niche) not only generate the entire intestinal epithelium, but give rise to all the neoplastic cells in mice colon tumors [57]. It was shown that the proportion of CD133+ cells in colon cancer metastases is higher than in primary tumors [58], which reflects the well known fact that metastatic lesions are more resistant to treatment. However, another study has shown that only a knockdown of CD44, but not CD133, strongly prevented clonal formation and inhibited tumorigenicity in mice xenograft model [59]. Authors reported that $\mathrm{CD} 44^{+}$did not colocalize with $\mathrm{CD}_{133}{ }^{+}$cells within colorectal cancer. Similar results reported by Horst and colleagues showed that the expression of CD133 correlates with that of CD166, while both do not correlate with CD44 [60]. However, this data contradicts multiple reports which not only show colocalization of the CD133 and CD44 in several types of human cancer [13,17-20,61], but also suggest their combined expression as the best CSC marker [18,61]. Such inconsistency may be due to the high heterogeneity of clinical specimens, diversity of the experimental approaches, and lack of the specific CSC markers.

Therefore, we have selected the CD133high/CD44high cell phenotype to study CSC-targeted activity of a newgeneration taxoid, SB-T-1214 in three independent colon cancer cell lines. Given that this compound led to complete remission in in vivo colon cancer xenograft model (Pgp+ DLD-1), we hypothesized that it could modulate some stemness genes/signaling pathways. The traditional in vitro model, the monolayer of the bulk tumor cells, poorly represents normal physiological conditions and has limited relevance to the hierarchically organized in vivo tumors. In particular, this model is not optimal for stem cell-based studies, because even highly purified CSCs can undergo relatively fast differentiation after being placed in standard adherent cultures with serumcontaining medium, and therefore, observed drug responses will be related to the bulk tumor cells, not CSCs. However, in our previous studies we have found that short-term culturing of repeatedly sorted cells on type I collagen-coated surfaces in serum-free stem cell medium led not only to the retaining, but to significant increase of the ratios of the tumor-initiating cell phenotypes $[19,20]$. This data is in line with a recent study showing that human colorectal carcinoma cells grown on type I collagen in serum-free medium undergo an epithelial-mesenchymal-like transition and downregulation of E-cadherin and $\beta$-catenin at cell-cell junctions [52]. Authors have found that collagen type I inhibited cell differentiation, increased clonogenicity and promoted expression of CD133 and Bmil, indicating that it promoted expression of a stem cell-like phenotype in colon cancer cells. In this context, culturing the adherent to a type I collagen CSC-enriched cell population in a serumfree stem cell medium can provide a useful tool for the preliminary evaluation of the CSC-focused drug responses. However, altered cell-to-cell and cell-tomatrix contacts in monolayer cell cultures can affect their signal transduction pathways and response to treatment [62-65]; therefore, we studied the SB-T-1214 cytotoxicity using an alternative model: free-floating colon cancer spheroids induced by the purified colon cancer tumorigenioc cell phenotypes. A three-dimensional model of can- 
cer spheroids was established by Sutherland and colleagues $[66,67]$ more than three decades before the discovery of CSCs in human cancers. It is now well documented that this model is more closely related to original tumors with respect to cell morphology, metabolic and proliferative gradients, oxygen and drug penetration and cell-cell junctions compared to the traditional cancer cell monolayers [66-70]. In addition, cancer spheroids are organized hierarchically, similarly to the in vivo tumors, containing a relatively small population of the tumorigenic cells and a large spectrum of their progenitors and differentiated cells, which comprise a bulk mass of the tumor or spheroid [70-72]. Spheroid cultures favor the proliferation of undifferentiated cells and can be passaged for many generations, reflecting the fact that they contain a population of cells with profound self-renewal capacity. We have shown that both mice tumor xenografts and 3D spheroids induced by more purified CD133high/CD44high cells contained much higher ratios of cells with the original phenotype, and possessed higher tumorigenic and clonogenic potentials $[19,20]$. Similar findings were reported for metastatic breast cancer cells [73] and prostate cancer cells lines [16]. Many of the commonly used anti-cancer drugs induce about 20 -fold lower cytotoxicity against 3D cancer spheroids compared to monolayer cultures [74], and exhibit chemoresistance which recapitulates this resistant phenotype in vivo [39,62,74-78]. In this context, SB-T-1214 revealed promising cytotoxicity against CSC-induced floating colon spheroids. In contrast to earlier studies on 3D cell cultures, which were usually limited to the relatively short-term gross evaluation of the inhibition of spheroid growth and apoptosis, we have analyzed specific stem cell-related responses. Thus, using a stem cell-focused PCR array assay we have found that single treatment of the 3D spheroids induced by $\mathrm{CD} 133^{\text {high}} / \mathrm{CD} 44^{\text {high }}$ cell populations with relatively low concentrations of the SB-T-1214 resulted not only in significant down-regulation of the majority of stem cellrelated genes, but more importantly, led to a dramatic reduction of their sphere-forming capacity. In addition, the expression of several key regulators of pluripotency of the embryonic stem cells, Oct-4, Sox-2, Nanog, Lin-28 and c-Myc, was also inhibited after single treatment with $100 \mathrm{nM}$ of SB-T-1214 for 48 hours. The synergistic action of these tissue-specific transcription factors is a pivotal mechanism for determining cellular phenotypes and selfrenewal of embryonic stem cells. Thus, the introduction of four genes (Oct-3/4, SOX2, c-Myc, and Klf4) into adult fibroblasts can transform them into pluripotent stem cells $[50,51]$. It has been demonstrated later that Oct-3/4 and SOX2 are crucial transcriptional regulators whose absence makes induction of pluripotency impossible, and additional genes, including Klf4, c-Myc, Nanog and LIN28 are important for the induction efficiency [79]. There is growing data that the pluripotency markers are also expressed by CSCs. Thus, the CD133-positive cells isolated from lung cancer tissues possessed the characteristics of stem-like cells and malignant tumors and expressed Oct4 [80], which was linked to chemo- and radioresistant properties in lung cancer-derived $\mathrm{CD} 133^{+}$ cells. Expression of Oct $3 / 4$ and Sox 2 was also associated with an unfavorable clinical outcome [81]. Of interest, down-regulation of Lin-28 can lead to the rapid production of the mature Let- $7 \mathrm{~g}$ miRNAs, which are required for cell differentiation [82]. Therefore, significantly decreased levels of expression of stem cell-related genes in general, and shut-down of several major players, including Oct-4, Sox-2, c-Myc and Lin-28 after treatment with SB-T-1214 is promising, because it most likely means that treated CSCs in colonospheres were promoted to a more differentiated state. This data is important in the light of growing evidence indicating that standard anti-cancer therapies often promote selfrenewal of tumor-initiating cells and further resistance to treatment [28-30]. CSC resistance to treatment may be due to several mechanisms, including overactivated $A B C$ transporters, high capacity for DNA repair and activated anti-apoptotic machinery [43-45]. It was recently demonstrated that treatment with 5-FU and oxaliplatin, a standard therapy for metastatic colon cancer, induced up to 30-fold enrichment of CD133+ and up to 2-fold enrichment of CD44+ cells in HT29 cell line [31]. This data is in line with our observation that after a single treatment with $100 \mu \mathrm{M}$ Paclitaxel for $24 \mathrm{hr}$, the clonogenic potential of the dissociated HT29 and DLD-1 spheres cells was significantly increased, so we can assume that post-treatment spheroids contained a higher proportion of putative colon CSCs compared to untreated spheroids. Since we have studied the SB-T-1214 induced alterations in the stemness gene expression profiles using total cell lysates (equal amounts of the total RNA for PCR arrays and total protein for western blot analyses), the significant inhibition of the stem cell-related genes induced by SB-T-1214 is promising.

\section{Conclusions}

In conclusion, we report here that a new-generation taxoid, SB-T-1214, possesses significant activity against 3D colon cancer spheroids induced by and enriched with drug resistant tumorigenic CD133 ${ }^{\text {high}} / \mathrm{CD} 44^{\text {high }}$ cell populations, and efficiently inhibits the expression of a majority of stem cell-related genes, including several key regulators of pluripotency and self-renewal of embryonic stem cells. Therefore, our data indicates that the longterm efficacy of SB-T-1214 against drug resistant colon tumors in vivo $[49,83]$ may be explained by down-regulation of multiple stem cell-related genes in tumorigenic cell populations, in addition to known efficacy of taxoids 
as a mitotic poisons due to their binding to microtubules [84] in the proliferating pool of cancer cells. These findings should be further tested across a large series of clinical specimens of primary and metastatic lesions of colon cancer.

\section{Methods \\ Cells and Culture systems}

Standard HCT116 cells derived from a poorly-differentiated human colonic adenocarcinoma (ATCC) were maintained at SBU Cell Culture Facility. Before sorting, cells were grown in standard conditions (DMEM with 10\% FCS, on uncoated flasks or dishes) at 50-75\% confluency. Isolated candidate CSC phenotypic subpopulations of colon cancer cells were counted, resuspended in a serumfree Mesenchymal stem cell medium (MSCBM; Lonza, Walkersville, MD) and cultured in two different settings: either as adherent to a type I collagen (Biocoat; Becton Dickenson, Bedford, MA), or as free-floating spheroids.

\section{CSC Purification and Abs}

Cells were labeled with one or several markers conjugated with different fluorescent dyes, including anti-human CD133/2-APC (clone 293C3; Miltenyi Biotec, CA, USA); CD166-PE (clone 105902; R\&D Systems, MN, USA); CD44-FITC (clone F10-44-2), CD44-PE (clone F10-44-2; Invitrogen/Biosources, USA); CD44v6-FITC (clone 2F10; R\&D Systems, USA), $h$ EpCAM-FITC (Biosource, CA, USA). Antibodies were diluted in buffer containing $5 \%$ BSA, 1 mM EDTA and 15-20\% blocking reagent (Miltenyi Biotec, CA, USA) to inhibit unspecific binding to nontarget cells. After $15 \mathrm{~min}$ incubation at $4^{\circ} \mathrm{C}$, stained cells were sorted with multiparametric flow cytometry with BD FACS Aria cell sorter (Becton Dickinson, CA) in sterile conditions.

For immunohistochemical analysis $h$ EpCAM-FITC (Biosource, CA, USA), biotin-conjugated anti-human CD133 as primary Abs (Miltenyi Biotec, CA, USA) and streptavidin-FITC (BD Pharmingen, USA) as a secondary Abs were used.

\section{Generation of floating multucellular spheroids}

Four hunderd cells of particular phenotype were seeded on each well of the Ultra-Low Attachment (ULA) 6-well plate (Corning, Lowell, MA) in serum-free MSCB medium containing 10-25\% Matrigel matrix (BD Biosciences) and examined after 1 week of culturing under standard conditions. Fresh medium was added after one week of culturing, every third day.

\section{Sphere propagation}

After initial culturing during 1-2 weeks on ULA plates, primary spheres were gently disaggregated by repeated pipetting and transferred into ULA flasks for further propagation and maintenance.

\section{Sphere formation assay}

Clonogenic potential of different phenotypic subpopulations was determined before and after treatment with SBT-1214. Cells were counted, resuspended in MSCBM/ Matrigel and plated on 48-well plates at a final count of 300 cells per well. One to two weeks after initiation, the plates were inspected for colony (sphere) growth, the number of colonies within each well was quantified by phase contrast microscopy and representative fields were photographed.

Isolation of the CSC populations from peritoneal wash of colon cancer patients and solid tumors, as well as induction of the mouse tumor xenografts, were carried out as we described elsewhere [20].

\section{Drug Treatment \\ In vivo cytotoxicity}

All experiments involving the use of animals were performed in accordance with SBU institutional animal welfare guidelines. Initially, the SB-T-1214 was evaluated for its efficacy against a drug-resistant human colon tumor xenograft (Pgp+) DLD-1 in severe combined immune deficient mice (SCID). Taxoid was administered intravenously at three doses 3 times using 3 day regimens $(\mathrm{q} 3 \mathrm{~d} \times$ 3 , on day 5,8 , and 11 ), starting from day 5 after DLD-1 subcutaneous tumor implantation.

\section{Cell death}

was analyzed with flow cytometry using either Annexin V/PI staining (BD PharMingen) or Live/Dead assay (BioVision, $\mathrm{CA}$ ) as recommended by the manufacturers.

\section{In vitro cytotoxicity}

was studied in two settings: a) using adherent type-I collagen monolayer cultures of freshly isolated CD133high/ CD44high cells; and b) three-dimensional cultures of floating multicellular spheroids induced by CD133igh/ CD44high and CD133-negative cells.

\section{Adherent to type I collagen cultures}

The CD133high/CD44high cells $\left(4-5 \times 10^{3}\right.$ cells/well were seeded onto the type I collagen-coated 6 -well plates, and the experiments were initiated $24 \mathrm{~h}$ later, upon sub-confluency. The regular MSCB medium was replaced with treatment media containing SB-T-1214 at selected concentrations $(0.001-0.1 \mu \mathrm{g} / \mathrm{ml})$. Treatment media was removed $24 \mathrm{hr}$ later, followed by washing with regular MSCBM and dissociation of cells with an Enzyme-free dissociating reagent (Chemicon International). Upon termination (48 hr from start), cell viability and cell death was analyzed through flow cytometry.

\section{D culture}

Cytotoxicity studies were carried out when floating spheroids induced by different cell phenotypes reached about $400-500 \mu \mathrm{m}$ in diameter. Spheres were resuspended in the drug-containing MSCBM $(0.01-0.1 \mu \mathrm{g} / \mathrm{ml})$ 
and either plated on ULA 48-well plates (5-10 spheres/ well) for microscopy or remained in ULA flasks if a larger number of sphere cells was required for FACS, PCR array, western blot and other analyses. After treatment with the drug for 48 hours, spheroids/cells were rinsed twice in PBS, centrifuged for $5 \mathrm{~min}$ at 1,000 rpm, and incubated in regular MSCBM for $24 \mathrm{hr}$. Then, rinsed spheroids/cells were dissociated with an Enzyme-free dissociating reagent and single cell suspensions were further analyzed.

\section{PCR ArrayAssay}

Stem cell-specific gene expression profiles were studied with the PCR Array assay (SABiosciences, CA) in accordance with the manufacturer's recommendations. Briefly, total RNA was isolated from different cell populations or whole floating spheroids using PARIS kit (Ambion). Up to $1 \mu \mathrm{g}$ of total RNA was treated with DNase and cDNA was prepared using RT ${ }^{2}$ First Strand kit. For each analysis, pairs of the test and control cDNA samples were mixed with $\mathrm{RT}^{2} \mathrm{qPCR}$ Master mix and distributed across the PCR array 96-well plates, each of which contained 84 stem cell-related probes and control housekeeping genes. After cycling with real-time PCR (Opticon M) Research or ABI 7300, Applied Biosystems), obtained amplification data (fold-changes in $C_{t}$ values of all the genes) was analyzed with SABiosciences software.

\section{Western blotting}

Cell pellets were suspended in Lysis Buffer (Active Motif, $\mathrm{CA}$ ) and incubated for $10 \mathrm{~min}$ on ice on a rocking platform. After brief vortexing, cell lysates were centrifuged at $4,000 \mathrm{~g}$ for $30 \mathrm{~min}$ at $4^{\circ} \mathrm{C}$. The protein content in the supernatant was determined by a Bradford method, and equivalent amounts of total proteins $(10 \mu \mathrm{g})$ were resolved on 10\% SDS-PAGE gel. After transferring to a polyvinylidene fluoride membrane, levels of various proteins were determined by Western blot analysis using antibodies specific for Oct4, Sox2, Nanog, Lin-28, c-Myc, GAPDH and $\beta$-actin, respectively $\left(1: 500\right.$ dilution, $4^{\circ} \mathrm{C}$, overnight). Following incubation with peroxidase-conjugated secondary Abs (anti-rabbit IgG; ECL, UK) for $1 \mathrm{hr}$ at $25^{\circ} \mathrm{C}$, blots were developed using the enhanced chemiluminesens (ECL) reagents. Alternatively, the blots were washed three times with PBST and incubated with AlexaFluor 680-conjugated goat anti-rabbit secondary antibody (Invitrogen) for $1 \mathrm{hr}$. Blots were then washed three times with PBST, twice with water, and the image captured on an Odyssey Infrared Imaging System (Li-Cor Biosciences).

\section{Statistical analysis}

The statistical significance of differences was determined using Student's $t$-test. $P<0.05$ was considered statistically significant.

\section{List of abbreviations}

CSCs: cancer stem cells; MSCBM: mesenchymal stem cell basal medium; SB-T-1214: new-generation taxoid; ULA: ultra low attachment plates.

\section{Competing interests}

The authors declare that they have no competing interests.

\section{Authors' contributions}

GIB conducted and carried out this project, reviewed and evaluated all the experimental data. YW, MD, EZ and JJ participated in PCR array analysis. AS, HW and SZ carried out western blotting. YL participated in sphere formation assay and data analysis. RR was responsible for cell culture. KS provided a histopathological evaluation of the mice tumor xenografts. All authors red and approved the final version.

\section{Acknowledgements}

We thank Drs. Stanley Zucker and Tomas Zimmerman for the evaluation of the in vivo efficacy of the SB-T-1214. We acknowledge the expert technical assistance of Stephanie Burke with histological preparation of the mice tumor xenografts. This work was supported by the NYSTAR grant 1072170, and in part by the NIH RO1CA 103314-18A1 and NIH R01GM063075.

\section{Author Details}

1Department of Pathology, SUNY Stony Brook, NY, USA, 2Institute of Chemical Biology \& Drug Discovery, SUNY Stony Brook, NY, USA, ${ }^{3}$ Department of Emergency Medicine, North Shore University Hospital, NYU School of Medicine Manhasset, NY, USA and ${ }^{4}$ Department of Molecular Genetics and Microbiology, SUNY Stony Brook, NY, USA

Received: 26 September 2009 Accepted: 14 July 2010 Published: 14 July 2010

\section{References}

1. Jemal A, Siegel R, Ward E, Hao Y, Xu J, Thun MJ: Cancer statistics. CA Cancer J Clin 2009, 59:225-249.

2. Kamb A, Wee $S$, Lengauer $C$ : Why is cancer drug discovery so difficult? Nature Rev Drug Discovery 2007, 6:115-120.

3. Dalerba P, Cho RW, Clarke MF: Cancer Stem Cells: Models and Concepts. Annual Rev Med 2007, 58:267-284.

4. Singh SK, Clarke ID, Terasaki M, Bonn VE, Hawkins C, Squire J, Dirks PB: Identification of a cancer stem cell in human brain tumors. Cancer Res 2003, 63:5821-5828

5. Liu G, Yuan X, Zeng Z, Tunici P, Ng H, Abdulkadir IR, Lu L, Irvin D, Black KL, YU JS: Analysis of gene expression and chemoresistance of CD133+ cancer stem cells in glioblastoma. Mol Cancer 2006, 5:67.

6. Bussolati B, Bruno S, Grange C, Buttiglieri S, Deregibus MC, Cantino D, Camussi G: Isolation of renal progenitor cells from adult human kidney. Am J Pathol 2005, 166:545-555.

7. Suetsugu A, Nagaki M, Aoki H, Motohashi T, Kunisada T, Moriwaki H: Characterization of CD133+ hepatocellular carcinoma cells as cancer stem/progenitor cells. Biochem and Biophys Res Comm 2006, 351:820-824.

8. Yin S, Li J, Hu C, Chen X, Yao M: CD133 positive hepatocellular carcinoma cells posess high capacity for tumorigenicity. Int J Cancer 2007, 120:1444-1450.

9. O'Brien CA, Pollett A, Gallinger S, Dick J: A human colon cancer cell capable of initiating timor growth in immunodeficient mice. Nature 2007, 445:106-110.

10. Ricci-Vitiani L, Lombardi DG, Pilozzi E, Biffoni M, Todaro M, Peschle C, De Maria R: Identification and expansion of human colon-cancer-initiating cells. Nature 2007, 445:111-115.

11. Hermann PC, Huber SL, Herrler T, Aicher A, Ellwart JW, Guba M, Bruns CJ, Heeschen C: Distinct Populations of Cancer Stem Cells Determine Tumor Growth and Metastatic Activity in Human Pancreatic Cancer. Cell Stem Cell 2007, 1:313-323.

12. Shmelkov SV, Clair R, Lyden D, Rafii S: AC133/CD133/Prominin-1. Int J Biochem Cell Biol 2005, 37:715-719. 
13. Collins AT, Berry PA, Hyde C, Stower MJ, Maitland NJ: Prospective identification of tumorigenic prostate cancer stem cells. Cancer Res 2005, 65:10946-51.

14. Jin L, Hope KJ, Zhai Q, Smadja-Joffe F, Dick JE: Targeting of CD44 eradicates human acute myeloid leukemic stem cells. Nat Med 2006, 10:1167-74

15. Krause DS, Lazarides K, von Andrian UH, Van Etten RA: Requirement for CD44 in homing and engraftment of BCR-ABL-expressing leukemic stem cells. Nat Med 2006, 10:1175-80.

16. Patrawala L, Calhoun T, Schneider-Broussard R, Li H, Bhatia B, Tang S, Reilly JG, Chandra D, Zhou J, Claypool K, Coghlan L, Tang DG: Highly purified $\mathrm{CD} 44^{+}$prostate cancer cells from xenograft human tumors are enriched in tumorigenic and metastatic progenitor cells. Oncogene 2006, 25:1696-1708.

17. Dalerba P, Dylla SJ, Park IK, Liu R, Wang X, Cho RW, Hoey T, Gurney A, Huang EH, Simeone DM, Shelton AA, Parmiani G, Castelli C, Clarke MF: Phenotypic characterization of human colorectal cancer stem cells. PNAS USA 2007, 104:10158-63.

18. Haraguch M, Ohkuma M, Sakashita H, Matsuzaki S, Tanaka F, Mimori K, Kamohara Y, Inoue H, Mori M: CD133+CD44+ Population Efficiently Enriches Colon Cancer Initiating Cells. Ann Surgical Oncol 2008, 15:2927-2933.

19. Rowehl RH, Crawford H, Dufour A, Leyfman Y, Ju J, Botchkina Gl: Genomic Analysis of Prostate Cancer Stem Cells Isolated from Highly Metastatic Cell Line. Cancer Genomics and Proteomics 2008, 5:301-309.

20. Botchkina IL, RowehI RA, Rivadeneira DE, Karpeh MS Jr, Crawford H, Dufour A, Ju J, Weng Y, Leyfman Y, Botchkina Gl: Phenotypic Subpopulations of Metastatic Colon Cancer Stem Cells: Genomic Analysis. Cancer Genomics and Proteomics 2009, 6:19-30.

21. Hong SP, Wen J, Bang S, Park S, Song SY: CD44-positive cells are responsible for gemcitabine resistance in pancreatic cancer cells. Internation I J Cancer 2009, 125(10):2323-31.

22. Takaishi, Shigeo, Okumura, Tomoyuki, Tu, Shuiping, Wang, Sophie SW, Shibata, Wataru, Vigneshwaran, Ramanathan, Gordon, Shanisha AK, Shimada, Yutaka, Wang, Timothy C: Identification of Gastric Cancer Stem Cells Using the Cell Surface Marker CD44. Stem Cells 2009, 27:1006-1020.

23. Ponta $\mathrm{H}$, Sherman L, Herrlich PA: CD44: From adhesion molecules to signalling regulators. Nat Rev Mol Cell Biol 2003, 4(1):33-45.

24. Marhaba R, Zöller M: CD44 in cancer progression: adhesion, migration and growth regulation. $J$ Mol Histol 2004, 35(3):211-31.

25. Gotley DC, Fawcett J, Walsh MD, Reeder JA, Simmons DL, Antalis TM: Alternatively spliced variants of the cell adhesion molecule CD44 and tumour progression in colorectal cancer. Br J Cancer. Br J Cancer 1996 74(3):342-51

26. Frank NY, Pendse SS, Lapchak PH, Margaryan A, Shlain D, Doeing C, Sayegh $\mathrm{MH}$, Frank $\mathrm{MH}$ : Regulation of progenitor cell fusion by ABCB5 Pglycoprotein, a novel human ATP-binding cassette transporter. J Biol Chem 2003, 278:47156-47165.

27. Frank NY, Margaryan A, Huang Y, Schatton T, Waaga-Gasser AM, Gasser M, Sayegh MH, Sadee W, Frank MH: ABCB5-mediated doxorubicin transport and chemoresistance in human malignant melanoma. Cancer Res 2005, 65:4320-4333.

28. Bao S, Wu Q, McLendon RE, Hao Y, Shi Q, Hjelmelad AB, Dewhirst MW, Bigner DD, Rich JN: Glioma stem cells promote radioresistance by preferential activation of the DNA damage response. Nature 2006, 444:756-760.

29. Liu G, Yuan X, Zeng Z, Tunici P, Ng H, Abdulkadir IR, Lu L, Irvin D, Black KL, YU JS: Analysis of gene expression and chemoresistance of CD133+ cancer stem cells in glioblastoma. Mol Cancer 2006, 5:67.

30. Bertolini G, Roz L, Perego P, Tortoreto M, Fontanella E, Gatti L, Pratesi G, Fabbri A, Andriani F, Tinelli S, Roz E, Caserini R, Lo Vullo S, Camerini T, Mariani L, Delia D, Calabrò E, Pastorino U, Sozzi G: Highly tumorigenic lung cancer CD133+ cells display stem-like features and are spared by cisplatin treatment. PNAS 2009, 106:16281-16286.

31. Dallas NA, Xia L, Fan F, Gray MJ, Gaur P, van Buren G, Samuel S, Kim MP, Lim SJ, Ellis LM: Chemoresistant colorectal cancer cells, the cancer stem cell phenotype, and increased sensitivity to insulin-like growth factor-I receptor inhibition. Cancer Res 2009, 69(5):1951-7.

32. Vlashi E, McBride WH, Pajonk F: Radiation responses of cancer stem cells. J Cell Biochem 2009, 108(2):339-42.
33. Liu Q, Nguyen DH, Dong Q, Shitaku P, Chung K, Liu OY, Tso JL, Liu JY, Konkankit V, Cloughesy TF, Mischel PS, Lane TF, Liau LM, Nelson SF, Tso CL: Molecular properties of CD133+ glioblastoma stem cells derived from treatment-refractory recurrent brain tumors. J Neurooncol 2009 94(1):1-19.

34. Dirks PB: Cancer: Stem cells and brain tumours. Nature 2006 444:687-688.

35. Eramo A, Ricci-Vitiani L, Zeuner A, Pallini R, Lotti F, Sette G, Pilozzi E, Larocca LM, Peschle C, De Maria R: Chemotherapy resistance of glioblastoma stem cells. Cell Death and Differentiation 2006, 13:1238-1241.

36. Woodward WA, Chen MS, Behbod F, Alfaro MP, Buchholz TA, Rosen JM: $W N T / \beta$-catenin mediates radiation resistance of mouse mammary progenitor cells. PNAS USA 2007, 104:618-623.

37. Todaro M, Alea MP, Stefano AB, Cammareri P, Vermeulen L, lovino F, Tripodo C, Russo A, Gulotta G, Medema JP, Stassi G: Colon cancer stem cells dictate tumor growth and resist cell death by production of interleukin-4. Cell Stem Cell 2007, 1:389-402.

38. Bleau AM, Hambardzumyan D, Ozawa T, Fomchenko El, Huse JT, Brennan CW, Holland EC: PTEN/PI3K/Akt pathway regulates the side population phenotype and ABCG2 activity in glioma tumor stem-like cells. Cell Stem Cell 2009, 4(3):226-35.

39. Al-Hajj M, Wicha MS, Benito-Hernandez A, Morrison SJ, Clarke MF: Prospective identification of tumorigenic breast cancer cells. PNAS USA 2003, 100:3983-3988.

40. Zeppernick F, Ahmadi R, Campos B, Dictus C, Helmke BM, Becker N, Lichter P, Unterberg A, Radlwimmer B, Herold-Mende CC: Stem Cell Marker CD133 Affects Clinical Outcome in Glioma Patients. Clin Cancer Res 2008, 14:123-129.

41. Maeda S, Shinchi HH, Kurahara HY, Mataki Y, Maemura K, Sato M, Natsugoe S, Aikou T, Takao SS: CD133 expression is correlated with lymph node metastasis and vascular endothelial growth factor-C expression in pancreatic cancer. British J Cancer 2008, 98:1389-1397.

42. Horst D, Kriegl L, Engel J, Kirchner $T$, Jung A: CD133 expression is an independent prognostic marker for low survival in colorectal cancer. Br J Cancer 2008, 99(8):1285-9.

43. Dean M, Fojo T, Bates S: Tumor stem cell and drug resistance. Nat Rev Cancer 2005, 5:275-284.

44. Donnenberg VS, Donnenberg AD: Multiple drug resistance in cancer revisited: the cancer stem cell hypothesis. J Clin Pharmacol 2005, 45:872-877.

45. Mimeault M, Hauke R, Mehra PP, Batra SK: Recent advances in cancer stem/progenitor cell research: therapeutic implications for overcoming resistance to the most aggressive cancers. J Cell Mol Med 2007, 11:981-1011.

46. Ojima I, Chen J, Sun L, Borella CP, Wang T, Miller ML, Lin S, Geng X, Kuznetsova L, Qu C, Gallager D, Zhao X, Zanardi I, Xia S, Horwitz SB, Mallen-St Clair J, Guerriero JL, Bar-Sagi D, Veith JM, Pera P, Bernacki RJ: Design, Synthesis and Biological Evaluation of New Generation Taxoids. J Med Chem 2008, 51:3203-3221.

47. Ehrlichová M, Václavíková R, Ojima I, Pepe A, Kuznetsova LV, Chen J, Truksa J, Ková J, Gut I: Transport and cytotoxicity of paclitaxel, docetaxel, and novel taxanes in human breast cancer cells. N-S Arch Pharmacol 2005, 372:95-105.

48. Kovar J, Ehrlichova M, Smejkalova B, Zanardi I, Ojima I, Gut I: Comparison of cell death-inducing effect of novel taxane SB-T-1216 and paclitaxel in breast cancer cells. Anticancer Res 2009, 29(8):2951-2960.

49. Kuznetsova L, Chen JL, Sun X, Wu A, Pepe JM, Veith P, Pera RJ, Bernacki, Ojima I: Syntheses and Evaluation of Novel Fatty Acid-2nd-generation Taxoid Conjugates as Promising Anticancer Agents. Bioorg Med Chem Let 2006, 16:974-977.

50. Takahashi K, Yamanaka S: Induction of pluripotent stem cells from mouse embryonic and adult fibroblast cultures by defined factors. Cell 2006, 126:663-676.

51. Takahashi K, Tanabe K, Ohnuki M, Narita M, Ichisaka T, Tomoda K, Yamanaka S: Induction of pluripotent stem cells from adult human fibroblasts by defined factors. Cell 2007, 131:861-872.

52. Kirkland SC: Type I collagen inhibits differentiation and promotes a stem cell-like phenotype in human colorectal carcinoma cells. $\mathrm{Br} J$ Cancer 2009, 101(2):320-326. 
53. Said HM, Polat B, Hagemann C, Anacker J, Flentje M, Vordermark D: Absence of GAPDH regulation in tumor-cells of different origin under hypoxic conditions in - vitro. BMC Res Notes 2009, 2:8.

54. Wagers AJ, Weissman IL: Plasticity of adult stem cells. Cell 2004, 116:639-648.

55. Jensen JB, Parmar M: Strengths and limitations of the neurosphere culture system. Mol Neurobiol 2006, 34:153-161.

56. Shmelkov SV, Butler JM, Hooper AT, Hormigo A, Kushner J, Milde T, St Clair R, Baljevic M, White I, Jin DK, Chadburn A, Murphy AJ, Valenzuela DM, Gale NW, Thurston G, Yancopoulos GD, D'Angelica M, Kemeny N, Lyden D, Rafii $\mathrm{S}$ : CD133 expression is not restricted to stem cells, and both CD133+ and CD133- metastatic colon cancer cells initiate tumors. J Clinical Investigation 2008, 118:2111-2120.

57. Zhu L, Gibson P, Currle DS, Tong Y, Richardson RJ, Bayazitov IT, Poppleton H, Zakharenko S, Ellison DW, Gilbertson RJ: Prominin 1 marks intestinal stem cells that are susceptible to neoplastic transformation. Nature 2009, 457(7229):603-607.

58. Puglisi MA, Sgambato A, Saulnier N, Rafanelli F, Barba M, Boninsegna A, Piscaglia AC, Lauritano C, Novi ML, Barbaro F, Rinninella E, Campanale C, Giuliante F, Nuzzo G, Alfieri S, Doglietto GB, Cittadini A, Gasbarrini A: Isolation and characterization of CD133+ cell population within human primary and metastatic colon cancer. Eur Rev Med Pharmacol Sci 2009:55-62.

59. Du L, Wang H, He L, Zhang J, Ni B, Wang X, Jin H, Cahuzac N, Mehrpour M, Lu Y, Chen Q: CD44 is of Functional Importance for Colorectal Cancer Stem Cells. Clin Cancer Res 2008, 14:6751-6760.

60. Horst D, Kriegl L, Engel J, Kirchner T, Jung A: Prognostic Significance of the Cancer Stem Cell Markers CD133, CD44, and CD166 in Colorectal Cancer. Cancer Investigation 2009, 27:844-850.

61. Zhu Z, Hao X, Yan M, Yao M, Ge C, Gu J, Li J: Cancer stem/progenitor cells are highly enriched in CD133(+)CD44(+) population in hepatocellular carcinoma. Int $J$ Cancer 2009.

62. Mueller-Klieser W: Three-dimensional cell cultures: from molecular mechanisms to clinical applications. Am J Physiol 1997, 273:C1109-C1123

63. Santini MT, Rainaldi G: Three-dimensional spheroid model in tumor biology. Pathobiology 1999, 67:148-157.

64. Dubessy C, Merlin JM, Marchal C, Guillemin F: Spheroids in radiobiology and photodynamic therapy. Crit Rev Oncol Hematol 2000, 36:179-192.

65. Durand RE, Olive PL: Resistance of tumor cells to chemo- and radiotherapy modulated by the three-dimensional architecture of solid tumors and spheroids. Methods Cell Bio/ 2001, 64:211-233. 2001

66. Inch WR, McCredie JA, Sutherland RM: Growth of nodular carcinomas in rodents compared with multi-cell spheroids in tissue culture. Growth 1970, 34:271-282

67. Sutherland RM, McCredie JA, Inch WR: Growth of multicellular spheroids in tissue culture as a model of nodular carcinomas. J Nat Cancer Inst 1971, 46:113-120.

68. Hamilton G: Multicellular spheroids as an in vitro tumor model. Cancer Lett 1998, 131:29-34.

69. Csete M: Oxygen in the cultivation of stem cells. Stem cell biology: Development and plasticity, Ann NY Acad 2005, 1049:1-8.

70. Friedrich J, Siedel C, Ebner R, Kunz-Schughart LA: Spheroid-based drug screening: considerations and practical approach. Nature Protocols 2009, 4:309-324.

71. Sodek KL, Ringuette MJ, Brown TJ: Compact spheroid formation by ovarian cancer cells is associated with contractile behavior and an invasive phenotype. Int J Cancer 2009, 124(9):2060-2070.

72. Todaro M, D'Asaro M, Caccamo N, lovino F, Francipane MG, Meraviglia S, Orlando V, La Mendola C, Gulotta G, Salerno A, Dieli F, Stassi G: Efficient killing of human colon cancer stem cells by gammadelta $T$ lymphocytes. J Immunol 2009, 182(11):7287-96.

73. Grimshaw MJ, Cooper L, Papazisis K, Coleman JA, Bohnenkamp HR, Chiapero-Stanke L, Taylor-Papadimitriou J, Burchell JM: Mammosphere culture of metastatic breast cancer cells enriches for tumorigenic breast cancer cells. Breast Cancer Res 2008, 10(3):R52.

74. Kobayashi H, Man S, Graham CH, Kapitain SJ, Teicher BA, Kerbel RS: Acquired multicellular-mediated resistance to alkylating agents in cancer. PNAS USA 1993, 90:3294-3298

75. Mueller-Klieser W: Tumor biology and experimental therapeutics. Crit Rev Oncol Hematol 2000, 36:123-139.
76. Gaedtke L, Thoenes L, Culmsee C, Mayer B, Wagner E: Proteomic Analysis Reveals Differences in Protein Expression in Spheroid versus Monolayer Cultures of Low-Passage Colon Carcinoma Cells. J Proteome Res 2007, 6(11):4111-4118.

77. Barbone D, Yang TM, Morgan JR, Gaudino G, Broaddus VC: Mammalian target of rapamycin contributes to the acquired apoptotic resistance of human mesothelioma multicellular spheroids. J Biol Chem 2008, 283:13021-13030

78. Desoize B, Jardillier J: Multicellular resistance: a paradigm for clinical resistance? Crit Rev Oncol Hematol 2000, 36:193-207.

79. Yu J, Vodyanik MA, Smuga-Otto K, Antosiewicz-Bourget JلL, Tian S, Nie J, Jonsdottir GA, Ruotti V, Stewart R, Slukvin II, Thomson JA: Induced Pluripotent Stem Cell Lines Derived from Human Somatic Cells. Science 2007, 318:1917-1920

80. Chen YC, Hsu HS, Chen YW, Tsai TH, How CK, Wang CY, Hung SC, Chang YL, Tsai ML, Lee YY, Ku HH, Chiou SH: Oct-4 expression maintained cancer stem-like properties in lung cancer-derived CD133-positive cells. PLoS One 2008, 3(7):e2637.

81. Wang Q, He W, Lu C, Wang Z, Wang J, Giercksky KE, Nesland JM, Suo Z Oct $3 / 4$ and Sox2 are significantly associated with an unfavorable clinical outcome in human esophageal squamous cell carcinoma. Anticancer Res 2009, 29(4):1233-41.

82. Park IH, Zhao R, West JA, Yabuuchi A, Huo H, Ince TA, Lerou PH, Lensch MW, Daley GQ: Reprogramming of human somatic cells to pluripotency with defined factors. Nature 2008, 451(7175):141-6.

83. Ojima I, Das M: Recent Advances in the Chemistry and Biology of New Generation Taxoids. J Nat Prod 2009, 72(3):554-65.

84. Jordan MA, Wilson L: Microtubules as a target for anticancer drugs. Nat Rev Cancer 2004, 4(4):253-65.

doi: $10.1186 / 1476-4598-9-192$

Cite this article as: Botchkina et al., New-generation taxoid SB-T-1214 inhibits stem cell-related gene expression in 3D cancer spheroids induced by purified colon tumor-initiating cells Molecular Cancer 2010, 9:192

\section{Submit your next manuscript to BioMed Centra and take full advantage of:}

- Convenient online submission

- Thorough peer review

- No space constraints or color figure charges

- Immediate publication on acceptance

- Inclusion in PubMed, CAS, Scopus and Google Scholar

- Research which is freely available for redistribution 